\title{
Determinants of Choice of Market Outlet Among Smallholder Poultry Farmers in Oyo State, Nigeria
}

Doi: 10.29023/alanyaakademik.341418

\author{
Mayokun Samuel OLUFADEWA
}

Department of Agricultural Economics, University of Ibadan, Ibadan, Nigeria

E-mail: mayokunsamuel@gmail.com

Mobile No: +234-8037626312

Ogheneruemu OBI-EGBEDI

Department of Agricultural Economics, University of Ibadan, Ibadan, Nigeria

Foluso Y. OKUNMADEWA

Department of Agricultural Economics, University of Ibadan, Ibadan, Nigeria

\begin{tabular}{|c|c|}
\hline & ABSTRACT \\
\hline Keywords: & $\begin{array}{l}\text { The study examined the factors that influence choice of market outlet among } \\
\text { smallholder poultry farmers in Oyo state, Nigeria. Primary data were }\end{array}$ \\
\hline Commercialization & collected using structured questionnaires. A multistage sampling technique \\
\hline Multinomial logit & was used to select 200 poultry farmers from two Agricultural Development \\
\hline Poultry farmers & Zones in Oyo state Nigeria. Multinomial logit results showed that household \\
\hline Smallholder & size, contractual agreement, road condition and total number of birds on the \\
\hline Oyo State & $\begin{array}{l}\text { farm influenced the choice of local market outlet while years of formal } \\
\text { education, years of poultry farming experience, price information and }\end{array}$ \\
\hline & access to extension officers influenced the choice of urban market outlet. \\
\hline & $\begin{array}{l}\text { The study recommends that extension officers should provide market } \\
\text { information to the poultry farmers regularly to enhance smallholder } \\
\text { farmers' commercialization }\end{array}$ \\
\hline
\end{tabular}

\section{INTRODUCTION}

\subsection{Background of the study}

Commercial agricultural production most times result in welfare improvements through the realization of comparative advantages, economies of scale, and from vibrant technological, institutional and organizational change effects that arise from the flow of concepts owing to exchange-based interactions (Romer 1993,1994). The main goal of agricultural commercialization is to achieve food self-sufficiency by the long transformation process from subsistence to semi-commercial and then to a fully commercialized agriculture (Pingali and Rosegrant, 1995). Haddad and Bouis (1990) pointed out that agricultural commercialization embraces the shift from subsistence farming to increased market-oriented production. In addition, it is commonly measured as the ratio of percentage value of marketed output to total farm production (Haddad and Bouis, 1990; Omiti et al. 2006). Also, commercialization of agriculture is the increased participation in the output market by farmers. Market-oriented production involves improvement of systems, which depends heavily on the intensification of production methods, adoption of new technology and farm mechanization (Omiti et al. 2006). 
According to von Braun and Immink (1994), the level of participation in the output market is the conventional way to determine agricultural commercialization.

Several policy makers and development economists have stressed the relevance of marketing in agricultural and economic development. Agricultural and food marketing is the major determinant of agricultural growth and contributes to overall development (Timmer 1997; Gani and Adeoti 2011). The key to increasing agricultural output such as poultry products in most developing countries is improving the farmers' productivity and ensuring the poultry farmers have access to markets regularly to sell their products. Poultry means a wide variety of feathered animals species raised for their products that are nutritionally and economically useful to man. Examples of poultry birds include chickens, duck, geese, turkey, guinea fowls, and pigeons. Normally, poultry production is about twice as effective as producing pork and three times more than producing beef due to its very short cycle, thus making it easy for producers to respond to the circumstances of the day. Little wonder, that poultry is a common kind of meat in many places around the world including Nigeria (Ad Bal, 2011).

Poultry is a major sub-sector in the livestock industry and the investment in poultry production is about eighty billion naira ( $\$ 80$ Billion) in Nigeria which makes it an essential livestock commodity (Omotosho, 2013). The poultry sub-sector offers the quickest returns to investment outlays in livestock enterprise due to its short gestation period, excellent feed conversion rate alongside being one of the cheapest, common and a good source of animal protein in the country (Ojo, 2002; Akintunde and Adeoti, 2014). Poultry production is the most efficient and cost-effective way of increasing the accessibility of high-protein food such as eggs known to provide people a perfectly balanced food containing all the essential vitamins, amino acids, and minerals (Branckeart et al, 2000).

Nweke, Spender and Lynam (2002) defined smallholder farmers as farmers that have a small farm size and produce mainly for home consumption (subsistence) and the surplus for sales. Smallholder farmers are the people who make up the great bulk of the population of farmers in most part of African countries (Hungwe, 2006). Akinwumi (1980) classified poultry farmers who keep 5000 birds and above as large-scale producers, between 500 and 4999 as medium-scale producers and less than 500 as small-scale producers. Smallholder poultry farmers are defined in this study as poultry farmers that have a small farm size and the flock of birds they raised is less than 500 birds. The poultry farmers focused on in this study are those engaged in chicken rearing especially layers and broilers.

Long distance to markets and lack of good roads is a source of major concern for rural smallholder farmers in developing countries. In addition, difficult market access leads to subsistence rather than market-oriented production systems and consequently restricts opportunities for income-generation (IFAD, 2003). Barret (2008) affirmed that market access has been identified as one of the serious factors affecting the performance of smallholder agriculture in developing countries, and in particular, least developed countries. The farmers face difficulties in transporting their produce to the markets which often force them to sell at the farm gate. Consequently, a large percentage of African smallholder farmers still produce largely for subsistence needs, producing small marketable surpluses and faces thin markets (Akinlade et al, 2013). Moreover, remoteness, scarce and poorly maintained roads, inadequate transport and storage facilities, and difficulties in accessing reliable information on products and prices prevent the smallholder farmers from participating in competitive markets, often restricting them to non-contestable markets controlled by a few, dominant 
purchasers (World Bank, 2008; Osmani and Hossain, 2015). Mostly, very few smallholder farmers commercialize their products in formal markets (Bongiwe and Micah, 2012). The issue of why most smallholder farmers who happen to make the greater percentage of the poor in developing countries self-select themselves out of the remunerative markets remains mostly unanswered (Zamasiya et al, 2014). In Nigeria, poultry production is still relatively low to meet the demand of the fast-expanding population. This is basically because most poultry farmers operate on a small scale with little opportunity for expansion and insurance (Adejoro, 2000).

This study will help us to know the factors affecting the preferred choice of market outlet among livestock farmers especially poultry farmers in Oyo State, Nigeria which may be farm gate, local market or urban market. In addition, the information from this study will give better insights to extension officers in order to help the smallholder poultry farmers to increase their profitability and sustainability. Policy makers would also use this information to formulate or improve existing policies in an effort to develop poultry production and marketing as well as motivate farmers to access high-value market where they can get greater prices for their products. Poultry farmers will find the information from this study valuable when deciding on which market outlet to sell poultry products for profitable marketing which will improve their level of income, decrease their malnutrition problems and ultimately reduce their level of poverty. This study will contribute to existing knowledge by providing factors that affect commercialization and choice of market outlet among livestock producers especially poultry farmers. In addition, this study will be relevant in providing vital information for holistic market planning and innovation in marketing. Researchers that want to explore the area of marketing will find this study relevant. It will also help in identifying interventions to unlock the welfare benefits associated with market driven agriculture and useful in institutional innovation in markets. The purpose of this study was to determine the factors influencing choice of preferred market outlet among the smallholder poultry farmers in Oyo State, Nigeria.

\section{MATERIAL AND METHODS}

\subsection{Study area}

The study was carried out in Oyo state, Nigeria. The state is situated in the Southwestern part of Nigeria. Ibadan is the capital city of Oyo state which is the largest city in West Africa. The state covers a total of $35,743 \mathrm{Km} 2$ of land mass and located within latitude $7^{\circ} 31$ and $9^{\circ} 121$ North of the Equator and longitude $2^{\circ} 471$ and $4^{\circ} 231$ East of the Meridian (NPC, 2006). Oyo state is located on the west coast of Nigeria and bounded in the north by Kwara State, in the east by Osun State, in the south by Ogun State, and in the west, it is partly bounded by both Ogun State and Republic of Benin. The State has 33 Local Government Areas (LGA) organized into four (4) agriculture zones under the Oyo State Agricultural Development Programme (OYSADEP). The four agricultural zones are Saki, Ogbomoso, Oyo and Ibadan Zones. There are two distinct ecological zones in Oyo state, the Rainforest in the south and Guinea Savannah in the North. The state enjoys tropical climate which can be divided into dry and wet seasons with relatively high humidity. The dry season lasts from November to March while the wet season begins from April and ends in October (NPC, 2006). 


\subsection{Source of data, sampling procedure and sample size}

Primary data used in this study were obtained from a cross-sectional survey of smallholder poultry farmers in the study area. Data collection involved the use of structured questionnaires to obtain information on demographic and farm characteristics such as age, gender, household size, size of land, marital status, poultry farming experience, years of formal education and choice of market outlet as well as constraints faced by the smallholder farmers with respect to commercialization during the production cycle.

A multistage sampling technique was employed in selecting the poultry farmers in the study area. At the first stage, two Agricultural Development Programme (ADP) Zone in Oyo state were randomly selected, which are Ibadan (Ibarapa) Zone and Oyo Zone. The second stage was executed by the random selection of two Local Government Areas (LGAs) from each of the two ADP Zones in which Egbeda and Lagelu LGAs were chosen from the Ibadan (Ibarapa) Zone while Afijio and Oyo East LGAs were chosen from Oyo Zone. The third stage was the random selection of two villages from each of the four Local Government Areas. The final stage involved the random selection of 74 poultry farmers from Egbeda LGA, 61 poultry farmers from Lagelu LGA, 49 poultry from Oyo East LGA, and 36 poultry farmers from Afijio LGA respectively proportionate to the size of the selected villages. 220 questionnaires were distributed to the smallholder poultry farmers. Only 200 questionnaires were eventually provided and used due to the incomplete information provided by some of the poultry farmers.

\subsection{Analytical techniques}

The analytical tools that were used based on the- objectives of this study include: descriptive statistics, multinomial logit analysis and mean analysis.

\subsubsection{Descriptive statistics and likert scale}

Descriptive statistics such as frequency distribution table, percentages, means and standard deviation were used to analyze demographic characteristics of smallholder poultry farmers.

\subsubsection{Multinomial Logit Model}

The choice of market outlet among smallholder poultry farmers was assessed by employing Multinomial Logit model following Sigei, Hillary and Lawrence (2014).

The multinomial logit model for choice of market outlet among the poultry farmers was specified as;

$P_{i j}=\beta_{0}+\beta_{1} X_{1}+\beta_{2} X_{2}+\ldots+\beta_{n} X_{n}+\varepsilon_{i}$

$\beta_{i}$ are parameters to be estimated

$\varepsilon_{i}=N\left(0, \delta^{2}\right) \quad$ where:

$P_{i j}=$ Choice of market outlets among poultry farmers

$($ Farm Gate $=0$ (Reference category), Local Market $=1$, and Urban Market $=2)$

The explanatory (independent) variables are:

$\mathrm{X} 1=\operatorname{Sex}($ Male $=1$, Female $=0)$ 
$\mathrm{X} 2$ = Years of Formal Education (Years)

X3 = Household Size (Headcount)

X4 = Group Marketing $($ Yes $=1$, No $=0)$

$\mathrm{X} 5=$ Vehicle Ownership (means of transport) $(\mathrm{Yes}=1$, No $=0$ )

$\mathrm{X} 6=$ Contract Marketing $(\mathrm{Yes}=1$, No $=0)$

$\mathrm{X} 7$ = Farming Experience (Years)

$\mathrm{X} 8=$ Access to Price Information $(\mathrm{Yes}=1, \mathrm{No}=0)$

X9 = Access to Extension Officer $($ Yes $=1$, No $=0)$

$\mathrm{X} 10=$ Distance to Market $(\mathrm{Km})$

$\mathrm{X} 11=\operatorname{Road}$ network $($ Good $=1$, otherwise $=0)$

$\mathrm{X} 12=$ Land Size (Hectares)

$\mathrm{X} 13$ = Number of birds produced (Headcount)

$\mathrm{X} 14=$ Access to credit $($ Yes $=1$, No $=0)$

The independent variables that determine choice of market outlet among poultry farmers were selected based on the studies carried out by Kuma et al. (2013), Mutai et al. (2013), Sigei et al. (2014), and Magogo et al. (2015).

To estimate the model, there is a need to normalize one category which is referred to as the "Reference State or Base Category". The reference state chosen for this study is the "Farm Gate" option which is the common market outlet among all smallholder poultry farmers.

Multinomial logistic regression was used because it permits the analysis of decisions across more than two categories, allowing the determination of choice probabilities for different categories (Wooldridge, 2002).

\subsubsection{Likert scale analysis using mean score}

A five-point Likert scale using mean analysis was used to identify the major constraints that hinder commercialization of smallholder poultry farmers in the study area by ranking them. The five-point Likert scale was used to analyze farmers' perception of the severity of each of the identified constraints by ranking them accordingly.

The scale was used as follows:

5 = Very severe; 4 = Severe; 3 = Uncertain; 2 = Not severe 1 = Not very severe

\section{RESULTS AND DISCUSSION}

\subsection{Demographic and farm characteristics of smallholder poultry farmers}

Table 1 revealed that majority $(80 \%)$ of the poultry farmers were male while a small number $(20 \%)$ were female. This shows that poultry farming is mostly dominated by males. This finding is consistent with the studies of Akintunde and Adeoti (2014) as well as Bamiro et al, (2013) where it was reported that poultry farming was predominantly a male occupation. The 
highest proportion (42\%) of the poultry farmers spent 13-18 years in school while very few (7\%) of the poultry farmers spent 6 years and below in school. This suggests that majority of the poultry farmers were educated. Most of the poultry farmers (84\%) were between $30-59$ years of age and younger and a minority of the poultry farmers were above 60 years of age. The mean age was found to be approximately 44 years. This shows that majority of the poultry farmers were in their active and productive years. The result agrees with the findings of Akintunde and Adeoti (2014) that majority of the poultry farmers were below 50 years with an average age of 45 years. Similar findings were reported by Bamiro et al. (2013) that majority of the poultry farmers were within the age range of 41-50 with an average age of 40 years. Majority (58\%) of the poultry farmer had a household size of 5 and above. The average household size of the poultry farmers in the study area was approximately 5 persons per household. The mean household size which is relatively large will serve the purpose of the family labor for the smallholder poultry farmers. This is in consonance with the findings of the study of Akintunde and Adeoti (2014) who reported that the mean household size was 5 members.

Table 1 results also revealed that the highest proportion $(43.5 \%)$ of the poultry farmers had a size of farmland within the range of $0.010-0.040$ hectares. The mean farmland size was 0.06 hectares which indicates that the poultry farmers were smallholders of land. Majority (73\%) of the poultry farmers had a farm distance to the market within the range of 0-5 kilometers, suggesting that many of the poultry farmers must cover a long distance while transporting poultry products from their farms to the market. Also, different combination of poultry enterprises was ventured into by the farmers engaged in the poultry business. Most (51\%) of the poultry farmers were involved in the production of layers only $25 \%$ of the poultry farmers were involved in the production of broilers only, while $24 \%$ of the poultry farmers were involved in the production of both layers and broilers. Just a few $(24.5 \%)$ of the poultry farmers had contact with livestock extension officer who provided adequate information on current market prices as well improved farming techniques while most (75.5\%) of the poultry farmers had no contact with livestock extension officer. This could be as a result of the negligence of duty on the part of the extension officers who did not visit the poultry farmers or could be attributed to the paucity of extension officers in Oyo State. The result is not in agreement with the study of Akintunde and Adeoti (2014) where most (73.9\%) of the poultry farmers had access to livestock extension officers who provided advisory services and adequate information. 
Table 1. Selected demographic and farm characteristics of the smallholder poultry farmers

\begin{tabular}{|c|c|c|c|c|}
\hline Variables & Frequency & Percentage (\%) & Mean & Standard Deviation \\
\hline \multicolumn{5}{|l|}{ Sex } \\
\hline Male & 160 & 80.0 & & \\
\hline Female & 40 & 20.0 & & \\
\hline Total & 200 & 100 & & \\
\hline \multicolumn{5}{|c|}{$\begin{array}{l}\text { Years of Formal } \\
\text { Education }\end{array}$} \\
\hline$\leq 6$ & 14 & 7.0 & & \\
\hline $7-12$ & 55 & 27.5 & & \\
\hline $13-18$ & 84 & 42.0 & & \\
\hline$\geq 19$ & 47 & 23.5 & & \\
\hline Total & 200 & 100 & & \\
\hline \multicolumn{5}{|c|}{ Age (Years) } \\
\hline Below 30 & 29 & 14.5 & 43.7 & 9.83 \\
\hline $31-40$ & 43 & 21.5 & & \\
\hline $41-50$ & 70 & 35.0 & & \\
\hline $51-60$ & 55 & 27.5 & & \\
\hline$\geq 60$ & 3 & 1.5 & & \\
\hline Total & 200 & 100 & & \\
\hline \multicolumn{5}{|c|}{ Household Size } \\
\hline $2-4$ & 84 & 42.0 & & \\
\hline $5-8$ & 111 & 55.5 & & \\
\hline $9-12$ & 5 & 2.5 & & \\
\hline Total & 200 & 100 & & \\
\hline
\end{tabular}


Table 1. Continued

\section{Farmland Size \\ (Hectares)}

$0.010-0.040$

43.5

0.06

0.03

$0.041-0.070$

82

41.0

$>0.070$

15.5

Total

Distance from

\section{Farm to Market}

$0-5$

73.0

4.76

4.01

$6-10$

22.0

$11-15$

6

3.0

$16-20$

4

2.0

Total

Poultry Enterprise

Broilers only

Layers only

Both Broilers and

Layers

Total

Access to

Extension Officer

Yes

No

Total
24.5

75.5

100

Source: Field Survey, 2015.

\subsection{Preferred choice of market outlet of the poultry farmers}

From Table 2, 20\% of the poultry farmers sell their output at the farm gate, $41 \%$ of the poultry farmers sell their output in the local markets while the remaining $39 \%$ of the poultry farmers sell their output at the urban markets. This implies that majority of the poultry farmers sell their output at the local markets. Although, the price offered at the local market is not too high, many poultry farmers opt for this market outlet because it is nearer to their farms, convenient to sell them at that place and to an extent guarantee a competitive market price for the poultry farmers which could serve as an incentive for commercialization. The 
result is contrary to the findings of Akinlade et al. (2013) and Adeoti et al, (2014) where farm gate was the most patronized market outlet of the farmers.

Table 2. Distribution of the poultry farmers based on choice of market outlet

\begin{tabular}{ccc}
\hline Market Outlet & Frequency & Percentage (\%) \\
\hline Farm gate & 40 & 20 \\
Local market & 82 & 41 \\
Urban Market & 78 & 39 \\
Total & $\mathbf{2 0 0}$ & $\mathbf{1 0 0}$ \\
\hline
\end{tabular}

Source: Field Survey, 2015.

\subsection{Determinants of the choice of market outlet among the smallholder poultry farmers}

Table 3 present the results of the Multinomial Logit model estimation of the factors determining the choice of local market outlet as compared to the farm gate option among smallholder poultry farmers in Oyo state, Nigeria. The result reveals that the log likelihood was -173.22451 and the Chi-square value was 75.42 implying that the likelihood ratio statistics were highly significant at $1 \%$ suggesting that the model had strong explanatory power as well as indicating the model had a good fit to the data.

The result reveals that out of the fourteen variables included in the model, four variables significantly influence the choice of local market outlet as compared to the farm gate option. The significant variables were household size, contract agreement, road condition and the total number of birds on the farm.

Household size was significant at 5\% and had a negative relationship with the choice of local market outlet for commercialization. The lower value of the odds ratio of 0.745 shows that as household size increases the likelihood of poultry farmers participating in a local market outlet was lower when compared to the farm gate option. The poultry farmers would prefer to sell their output at the farm gate instead of the local market outlet. This could have been so because a large household size increases domestic consumption requirements and may render households more risk averse. Furthermore, the farmer needs to supply household consumption before he/she sells and they only sell a little surplus at the farm gate rather than sell at the local market. The result is in dissonance with a priori expectation and not in accordance with the findings of Magogo et al, (2015) where an increase in the household size by one member increases the likelihood of selling the African Indigenous Vegetables (AIVS) at the local market because large households are able to produce more AIVs and provide manpower in carrying them to the local market to earn more income for their basic needs.

Contractual agreement (marketing) was significant at $10 \%$ and had a positive influence on the choice of local market instead of the farm gate option for commercialization. The high odds ratio of 2.515 suggests that poultry farmers who were under contract marketing had a higher likelihood of selling at the local market than at the farm gate. The result is in accordance with the findings of Jari and Fraser (2009), where households tend to increase in formal market participation with the availability of contractual agreements and contrary to the work of Sigei et al, (2014) who found that farmers who were under contract in marketing had a higher probability of selling their pineapples at farm gate and they opt to sell at farm gate to incur zero transaction cost. 
Road condition was significant at $10 \%$ and had a positive influence on the choice of local market. The high odds ratio of 2.591 in table 3 means that poultry farmers who had access to good road network from their farms to the market had a higher likelihood to sell their output at the local market where they will get competitive and high prices for their output rather than sell them at the farm gate which attracts lower prices. This result is consistent with the findings of Mutai et al. (2013) who argued that good road network reduces the cost of transportation for the farmer and hence makes it easy and cheaper for the farmer to access local town market which has better market conditions in terms of the large population of buyers and sellers.

The total number of livestock on the farm was significant at $5 \%$ and has a positive relationship with the choice of local market. The odds ratio of 1.004 in table 3 implies that smallholder poultry farmers who had a large number of livestock on the farm will more likely sell their output in the local market instead of the farm gate option. The increase in the number of livestock on the farm will make the farmer sell more birds in the local market which has a larger population of consumers and will result to increase his chances of selling most or all the livestock that was offered for sale and will be marketed at higher prices than the farm gate. This agrees with the study of Sigei et al. (2014) who found that an increase in the weight of pineapple yields by one kilogram increases the likelihood of selling at local market as compared to farm gate. Similarly, the result concurs with that of Chalwe (2011) who found more of the beans produced are sold to the private traders in the marketplaces than to the other households at the farm gate.

Table 3 also presents the results of the Multinomial Logit model estimation of the factors determining the choice of urban market outlet as compared to the farm gate option among smallholder poultry farmers in Oyo state, Nigeria. The result reveals that out of the fourteen variables included in the model, four variables significantly influence the choice of urban market outlet as compared to the farm gate option. The significant variables are years of formal education, years of experience in poultry farming, price information and access to extension officers.

Years of formal education was significant at $1 \%$ and had a negative influence on the choice of urban market outlet for output commercialization. The odds ratio of about 0.828 suggests that the smallholder poultry farmers who had more years of formal education will not likely sell their birds at the urban market outlet as compared to the farm gate. This could be attributed to the fact that an educated smallholder poultry farmer could be practicing subsistence farming and sell only the surplus birds or lack the means of transportation such as vehicle hence the farmer will prefer to sell at the farm gate so that he will not incur transportation cost (transaction cost). This finding is not in agreement with the study of Magogo et al. (2015) that since education level comes with knowledge, farmers are able to make informed decision and choose a lucrative marketing outlet for the commonly grown African Indigenous Vegetables (AIVS) which offers a higher marketing margin.

Years of experience in poultry farming was significant at 5\% and had a negative relationship with the choice of urban market outlet. The low odds ratio of 0.812 shows that more years of poultry farming experience did not increase the likelihood of a smallholder farmer in choosing an urban market instead of farm gate option. Hence, a farmer with more years of experience in poultry farming will more likely choose the farm gate as compared to the urban market outlet. This could be so especially if the poultry farmers are still engaged in 
subsistence farming for family consumption due to lack of resources such as land, labor, capital and only a little surplus is sold at the farm gate. The result is contrary to a priori expectations and does not concur with the studies of Kuma et al. (2013) where the likelihood of accessing cooperative (urban) milk market outlet was higher for farmers who had been in dairy farming for many years when compared to accessing individual consumer milk market outlet. Magogo et al. (2015) found that households with more experience in Agro-pastoralism are more exposed and venture into commercial activities like African Indigenous Vegetables (AIVs) in lucrative markets like urban markets as experience is formed with knowledge.

Price information was significant at 5\% and had a positive influence on the choice of urban market outlet. The odds ratio of 1.589 implies that the poultry farmers who had access to price information of the birds will be encouraged to sell in an urban market outlet instead of the farm gate. This implies that the poultry farmers will most likely increase their commercialization activities in the urban market outlet when they have adequate information of prices in that market. Essentially, price information helps the poultry farmer to know the prevailing prices and price trends in the market and helps them to plan on how they can maximize profit efficiently. The result is consistent with the findings of Jari and Fraser (2009) where availability of market price information resulted in an increase in commercialization.

Access to extension officer was significant at $10 \%$ and had a negative relationship with the choice of urban market outlet. The odds ratio of 0.257 reveals that the smallholder poultry farmers who were visited and had access to extension officers had a lower likelihood of selling their output in the urban market outlet as compared to the farm gate. This could be attributed to the fact that poultry farmers who accessed better extension services and had adequate information about current market prices and buyers' preferences might not have acted on the information in planning and decision making on how they can increase their profit from poultry production. In addition, the smallholder poultry farmers that had access to extension services could still be operating at the subsistence level and not able to expand their level of production. Therefore, the smallholder poultry farmer would rather prefer to sell their birds at the farm gate instead of the urban market outlet to reduce cost. This finding is not consistence with Kuma et al, (2013) which revealed that access to dairy extension services significantly affected accessing hotel/restaurant milk market outlet. 
OLUFADEWA, OBI-EGBEDI \& OKUNMADEWA

Table 3. Factors that influences the choice of local and urban market outlet among the sampled smallholder poultry farmers

\begin{tabular}{|c|c|c|c|c|c|c|}
\hline Variables & Coefficient & $\begin{array}{c}\text { Local } \\
\text { Market Std. } \\
\text { Error }\end{array}$ & $\begin{array}{l}\text { Odds } \\
\text { Ratio } \\
\text { (Exp. } \\
\beta \text { ) }\end{array}$ & Coefficient & $\begin{array}{l}\text { Urban Market } \\
\text { Std. Error }\end{array}$ & $\begin{array}{l}\text { Odds } \\
\text { Ratio } \\
\text { (Exp. } \\
\beta \text { ) }\end{array}$ \\
\hline Sex & 0.145199 & 0.5265076 & 1.156 & 0.9780436 & 0.6023754 & 0.817 \\
\hline $\begin{array}{l}\text { Years of Formal } \\
\text { Education }\end{array}$ & -0.0947547 & 0.0646239 & 0.909 & -0.1884252 & $0.0660517 * * *$ & 0.828 \\
\hline Household Size & -0.2937156 & $0.1456204 * *$ & 0.745 & 0.0328012 & 0.1413398 & 0.783 \\
\hline Group Marketing & -0.6135303 & 0.5399782 & 0.541 & -0.2000181 & 0.5352963 & 0.287 \\
\hline $\begin{array}{l}\text { Vehicle } \\
\text { Ownership }\end{array}$ & -0.3311339 & 0.4892078 & 0.718 & -0.2544037 & 0.5121774 & 0.284 \\
\hline $\begin{array}{l}\text { Contractual } \\
\text { Agreement }\end{array}$ & 0.9220822 & $0.511785 *$ & 2.515 & 0.5484537 & 0.5229955 & 0.621 \\
\hline $\begin{array}{l}\text { Years of Poultry } \\
\text { farming } \\
\text { Experience }\end{array}$ & -0.0490635 & 0.0409114 & 0.952 & -0.1151868 & $0.0469631 * *$ & 0.812 \\
\hline Price Information & -0.6243166 & 0.5533172 & 0.535 & 2.222612 & $0.8980194 * *$ & 1.589 \\
\hline $\begin{array}{l}\text { Access to } \\
\text { Extension Officer }\end{array}$ & 0.0493942 & 0.6650952 & 1.051 & -1.357831 & $0.7133852 *$ & 0.257 \\
\hline $\begin{array}{l}\text { Distance to } \\
\text { Market }\end{array}$ & 0.0518497 & 0.0707498 & 1.053 & 0.071551 & 0.0715436 & 0.934 \\
\hline Road Condition & 0.952201 & $0.5280629^{*}$ & 2.591 & 0.6866973 & 0.5442011 & 0.684 \\
\hline Farmland Size & -0.2380488 & 0.2921293 & 0.788 & -0.186678 & 0.3139364 & 0.448 \\
\hline $\begin{array}{l}\text { Total livestock on } \\
\text { the farm }\end{array}$ & 0.0036074 & $0.0015895^{* *}$ & 1.004 & 0.0027622 & 0.0017177 & 0.999 \\
\hline $\begin{array}{l}\text { Access to credit } \\
\text { facilities }\end{array}$ & -0.4896929 & 0.4911999 & 0.613 & -0.8305989 & 0.5325021 & 0.153 \\
\hline Constant & 2.905927 & 1.476 & 18.282 & 0.5747074 & 1.622586 & 0.074 \\
\hline \multicolumn{2}{|c|}{$\begin{array}{l}\text { Number of Observations } \\
\text { LR Chi }{ }^{2}(28) \\
\text { Prob. > Chi } \\
\text { Pseudo R } \\
\text { Log Likelihood }\end{array}$} & \multicolumn{2}{|c|}{$\begin{array}{l}=200 \\
=75.42 \\
=0.0000 \\
=0.1788 \\
=-173.22451\end{array}$} & & & \\
\hline \multicolumn{7}{|c|}{$\begin{array}{l}* * *, * *, * \text { indicate estimates significant at } 1 \%, 5 \% \text { and } 10 \% \text { level of } \\
\text { significance respectively }\end{array}$} \\
\hline
\end{tabular}

Source: Field Survey, 2015.

188 
Note: Farm gate option is the base category

\subsection{Major constraints experienced by the smallholder poultry farmers in the study area}

Table 4 reveals the list of constraints to commercialization in descending order of severity as experienced by the smallholder poultry farmers. The most severe constraints faced by the smallholder poultry farmers in Oyo State, Nigeria is long distance to market and the least severe constraints experienced is lack of farmers group or cooperatives among the poultry farmers.

Long distance to the market was the most severe constraint experienced by the smallholder poultry farmers in Oyo state, Nigeria. Majority of the poultry farmers within villages in Oyo State must travel several kilometers on the road to major markets such as Agbeni, Bodija and so on where they can sell their output at higher prices. The long distance is a serious concern for the poultry farmers because they incur a high transportation cost which is a major limiting factor. Insufficient working capital was the second most severe constraints experienced by the smallholder poultry farmers. This is a pointer to the fact that smallholder poultry farmers require enough working capital to grow their business which is not adequately available to them. Bad roads or poor road network was ranked as the third most severe challenge experienced by the farmers. Road is the only available means by which poultry birds and eggs are transported from the farms to the market. Bad roads will increase the cost of transportation (marketing cost of the smallholder poultry farmer. Inadequate access to credit ranked as fourth among the challenges experienced by the smallholder poultry farmers. This suggests that some poultry farmers did not belong to any farmers group or cooperative society where they could easily access credit facilities. Price instability ranked as fifth among the constraints affecting commercialization. This is because price instability and fluctuations in the market will affect the decision making of some of the poultry farmers.

Inadequate extension service was also a challenge experienced by the smallholder poultry farmers in Oyo state. It ranked as sixth among the severe constraints. This shows that the visit of extension officers to the poultry farmers was not frequent. Therefore, the farmers may likely not have enough information on modern farming practices and prevailing market prices among others. High cost of transportation ranked as seventh among the severe constraints faced by the smallholder poultry farmers. This is because the rural areas and villages are far away from the major markets and some roads network leading to the farms are in a deplorable condition. Lack of market information ranked as eighth among the list of severe constraints experienced by the poultry farmers. Many of the farmers do not have adequate information from reliable sources like extension officers, Ministry of Agriculture and so on about the prevailing prices of their output, kind of livestock required in the markets and alternative markets where they can sell their output. Pest and diseases outbreak ranked as ninth among the list of severe constraints. Though poultry farming is prone to pest and disease outbreak however in the study area it appears to be a minor constraint. Weather condition ranked as tenth among the list of severe constraints faced by the poultry farmers. Despite the fact that poultry farming is weather sensitive however it has not been a major threat to their production activities in the study area. Low level of government support was ranked eleventh. To the poultry farmers, it ranked low because they view it as a minor problem because to a large extent government had supported poultry farming in Nigeria by placing a ban on the importation of frozen poultry products into Nigeria recently in 2015. Lack of farmers group or cooperatives appears to be a very minor challenge to the poultry farmers as it was ranked 
twelfth. This could be justified by the fact that there are enough poultry farmers group such as Agbeloba Poultry Farmers Association, Poultry Association of Nigeria (PAN) among others. Though, some of the sampled respondents are not members of this farmers group due to personal reasons, the respondents do not consider it to be a severe constraint hampering their commercialization activities.

Table 4. Severity of constraints affecting commercialization among smallholder poultry farmers in descending form

\begin{tabular}{lcc} 
Major Constraints & Mean Score & Rank \\
\hline Bad roads or poor road network & 3.92 & $3^{\text {rd }}$ \\
Inadequate extension services & 3.77 & $6^{\text {th }}$ \\
Lack of farmers group or cooperatives & 3.34 & $12^{\text {th }}$ \\
Inadequate access to credit & 3.88 & $4^{\text {th }}$ \\
Long distance to market & 4.08 & $1^{\text {st }}$ \\
High cost of transportation (Transaction cost) & 3.70 & $7^{\text {th }}$ \\
Price instability & 3.87 & $5^{\text {th }}$ \\
Low level of government support & 3.38 & $11^{\text {th }}$ \\
Pest and diseases outbreak & 3.49 & $9^{\text {th }}$ \\
Insufficient working capital & 3.99 & $2^{\text {td }}$ \\
Lack of market information & 3.69 & $8^{\text {th }}$ \\
Weather problem & 3.45 & $10^{\text {th }}$ \\
\hline
\end{tabular}

Source: Field Survey, 2015.

\section{CONCLUSION AND RECOMMENDATIONS}

The paper established that most of the poultry farmers sell their output at the local markets. Majority of the smallholder poultry farmers were involved in the production of layers only. Many the poultry farmers do not have access to extension officers. Multinomial logit model results were in two aspects as regards to the determination of the factors affecting the choice of market outlet among the smallholder poultry farmers in Oyo state. The first aspect of the multinomial logit result reveals that four out of the fourteen variables included in the model was significantly influenced by the choice of local market outlet as compared to the farm gate option. The significant variables were household size, contract agreement, road condition and the total number of livestock on the farm. The second aspect of the multinomial logit result showed that four out of the fourteen variables included in the model significantly influenced the choice of urban market outlet as compared to the farm gate option. The significant variables were years of formal education, years of experience in poultry farming, price information and access to extension officers. The most severe constraint faced by the smallholder poultry farmers was long distance to market and the least severe constraint was the lack of farmers group or co-operatives. 
Price information of the poultry output such as birds and eggs should be made available to the farmers at all time through mass media (radios, televisions) and extension officers to help the smallholder poultry farmers in planning and decision making on their farms. Also, there is a need to employ more extension officers who should visit the smallholder poultry farmers more frequently so as provide better extension services such as training the poultry farmers on improved farming practices and providing adequate information on the current market prices of their output, as well as the change in consumer preferences. Government at all levels should assist in the improvement of rural infrastructure especially farm-to-market which would facilitate convenient and faster delivery of farm output to consumers in various market outlets.

\section{ACKNOWLEDGEMENTS}

My profound gratitude goes to the project supervisor of my Masters' thesis, Professor Foluso Okunmadewa for the unique opportunity to learn from his wealth of knowledge. Also, I sincerely appreciate my sub-supervisor, Dr. (Mrs) Obi-Egbedi for her constructive corrections, guidance and contributions to the quality and scope of this research paper. Finally, I am deeply grateful to the entire teaching staff of the Department of Agricultural Economics, University of Ibadan, Nigeria.

\section{REFERENCES}

AD Bal (2011). Room for Alternatives, World Poultry Magazine 27(7): 5.

ADEOTI, A. OLUWATAYO I.B. \& SOLIU, R., (2014). Determinants of Market Participation among Maize Producers in Oyo State, Nigeria. British Journal of Economics, Management and Trade 4(7): 1115-1127.

ADEJORO, S.O. (2000). Hand Book for Poultry Practitioners and Consultants. Jilog Nigeria Company Ibadan, Oyo State, Nigeria.

AKINLADE, J. Roseline, BALOGUN, L. Olubunmi \& OBISESAN A. Adekemi (2013). Commercialization of Urban Farming: The Case of Vegetable Farmers in Southwest Nigeria. Invited paper presented at the 4th International Conference of the African Association of Agricultural Economists, September 22-25, 2013, Hammamet, Tunisia.

AKINTUNDE, O. \& ADEOTI, A.I. (2014). Assessment of Factors Affecting the Level of Poultry Disease Management in Southwest, Nigeria. Trends in Agricultural Economics 7(2):41-56.

AKINWUMI, J.A. (1980). Developing the Nigeria Poultry Industry: A case study of Hatchery and Feeds (Unpublished Master's Thesis). University of Ibadan, Ibadan, Nigeria.

BAMIRO, O.M., OTUNAIYA, A.O. \& ADEJUMO, I. (2013). Profit Efficiency in Poultry Production in peri-urban Lagos, Nigeria. International Journal of Applied Agricultural and Apicultural Research (IJAAAR) 9 (1): 120-130.

BARRET, C.B. (2008). Smallholder market participation: Concepts and evidence from eastern and southern Africa. Food Policy 33: 299-317. 
BONGIWE, G. Xaba \& MICAH, B. Masuku (2012). Factors Affecting the Choice of Marketing Channel by Vegetable Farmers in Swaziland. Sustainable Agriculture Research 2(1):112-123.

BRANCKEART, R.D.S., GAVIRA, L., JALLADE, J. \& SEIDER, R.W. (2000). Transfer of technology in poultry production for developing countries. Sustainable Development Department, Food and Agriculture Organization of the United nations, Rome, Italy.

GANI, B.S. \& ADEOTI, A.I. (2011). Analysis of Market Participation and Rural Poverty among Farmers in Northern Part of Taraba State, Nigeria Journal of Economics 2(1): 23-36.

HADDAD, L. J. \& BOUIS, H. E. (1990). Agricultural commercialization, nutrition and the rural poor: A study of Philippine farm households. International Food Policy Research Institute (IFPRI), Washington, DC.

HUNGWE, S.D. (2006). The African smallholder farmers' perspective 24th Ipc seminar victoria falls, Zimbabwe 14-15 October 1999. Available online at: http:/www.agritrade.org /publications/DW\%20books/pdfs/hungwe.pdf.

IFAD (2003). Promoting Market Access for the Rural Poor in Order to Achieve the Millennium Development Goals. Discussion Paper. Rome, Italy.

JARI, B. \& FRASER, C.G. (2009). An Analysis of Institutional and Technical Factors Influencing Agricultural Marketing amongst Smallholder Farmers in the Kat River Valley, Eastern Cape, South Africa. African Journal of Agricultural Research 4 (11): 1129-1137.

KUMA, B., BAKER, D., GETNET K. \& KASSA B. (2013). Factors affecting milk market outlet choices in Wolaita zone, Ethiopia. African Journal of Agricultural Marketing 1(2): 24-31.

MAGOGO J. R., MSHENGA P. M., SAIDI M., NKURUMWA A., \& ORADU S.I. (2015). Determinants of Choice of Marketing Outlets for African Indigenous Vegetables among the Agro-Pastoral Maasai of Narok and Kajiado Counties of Kenya. Journal of Economics and Sustainable Development 6(8): 29-42.

MUTAI, K. B., ELVI N. A, AUGUSTUS S. M., LAWRENCE K. K., \& MARY C. M. (2013). Determinants of smallholder sweet potato farmers' participation in different market options: The case of Vihiga County, Kenya. Journal of Development and Agricultural Economics 5(8): 314-320.

NPC (2006). Analysis of Nigerian 2006 census results National Population Commission (NPC): Abuja, Nigeria.

NWEKE, F., SPENDER, C. \& LYNAM, J. (2002). The Cassava Transformation: Africa's Best Kept Secret. Michigan State University Press, East Lansing Michigan, U.S.A.

OJO, S.O. (2002). Analysis of the three risk factors in commercial poultry production in Osun State, Nigeria. Proceedings of the 27th Annual Conference of Nigeria Society for 
Animal production, March 17-21, 2002, Federal University of Technology, Akure, Nigeria.

OMITI, J., MCCULLOUGH, E., OTIENO, D., MADELON, M., NYANAMBA, T. \& MURAGE, A. (2006). Participatory prioritization of issues in smallholder agricultural commercialization in Kenya. Discussion Paper No. 64, Kenya Institute for Public Policy Research and Analysis (KIPPRA), Nairobi.

OMOTOSHO, M. (2013). Livestock Sub-Sector and Transformation Agenda in Nigeria: Problems and Prospects. A paper presented at the 47th Annual Conference of Agricultural Society of Nigeria in Ibadan.

OSMANI A.G. \& HOSSAIN, E. (2015). Market Participation Decision of Smallholder Farmers and its Determinants in Bangladesh. Journal of Economics of Agriculture 62(1): 163-179.

PINGALI, L.P. \& ROSEGRANT, M.W. (1995). Agricultural Commercialization and Diversification: Process and Polices. Food Policy 20(3): 171-185.

ROMER, P. (1993). Idea gaps and object gaps in economic development. Journal of Monetary Economics 32(3): 543-573.

ROMER, P. (1994). New Goods, Old Theory and The Welfare cost of trade restrictions. Journal of Development Economics 43(1): 5-38.

SIGEI, G., HILLARY, B., \& LAWRENCE K. (2014) Determinants of Market Participation among Small-scale Pineapple Farmers in Kericho County, Kenya. Munich Personal RePEc Archive (MPRA) Paper No. 56149. Retrieved from http://mpra.ub.unimuenchen.de/56149/

TIMMER, C.P. (1997). Farmers and Markets: The Political Economy of New Paradigms. American Journal of Agricultural Economics 79(2): 621-627.

VON BRAUN, J. \& IMMINK, M.D.C. (1994). "Non-traditional vegetable crops and Food Security among Smallholder farmers in Guatemala." In: von Braun, J., and E. Kennedy (eds.). Agricultural Commercialization, Economic Development, and Nutrition. Johns Hopkins University Press, Baltimore, MD, pp. 189-203.

WOOLDRIDGE, J.M. (2002). Econometric Analysis of Cross Section and Panel Data. Cambridge: MIT Press.

WORLD BANK (2008). World Development Report 2008: Agriculture for development. Washington DC, USA.

ZAMASIYA, B., NELSON, M., KEFASI N. \& SHEPHARD S. (2014). Determinants of soybean market participation by smallholder farmers in Zimbabwe. Journal of Development and Agricultural Economics 6 (2): 49-56 